\title{
Eficácia do Programa de Remediação Fonológica e Leitura no distúrbio de aprendizagem $* * *$
}

\author{
Efficacy of the Reading and Phonological Remediation Program in \\ learning disabilities
}

\author{
Cláudia da Silva* \\ Simone Aparecida Capellini**
}

*Fonoaudióloga. Doutoranda em Educação pela Faculdade de Filosofia e Ciências da Universidade Estadual Paulista (FFC - Unesp) - Marília - SP. Endereço para correspondência: Rua Cláudio Manuel da Costa, 76 - Apto. 304 - Marília - SP - CEP 17515-460 (claudiasilvafono@yahoo.com.br).

**Fonoaudióloga. Doutora em Ciências Médicas pela Faculdade de Ciências Médicas da Universidade Estadual de Campinas (FCM Unicamp) - Campinas - SP. Docente do Departamento de Fonoaudiologia e do Programa de Pós-Graduação em Educação da FFC - Unesp - Marília SP.

***Trabalho Realizado no Centro de Estudos da Educação e Saúde - FFC Unesp - Marília SP. Apoio: Coordenação de Aperfeiçoamento de Pessoal de Nível Superior (Capes).

Artigo Original de Pesquisa

Artigo Submetido a Avaliação por Pares

Conflito de Interesse: não

Recebido em 30.04.2009.

Revisado em 20.12.2009; 12.02.2010.

Aceito para Publicação em 22.04.2010.

\begin{abstract}
Background: the Phonological and Reading Remediation Program in learning disabilities. Aim: to verify therapeutic effectiveness of the Phonological and Reading Remediation Program in students with learning disabilities. Method: participants of this study were 40 students who were divided in the following groups: GI, subdivided in: GIE (10 students without learning disabilities submitted to the Phonological and Reading Remediation Program), GIC (10 students without learning disabilities who were not submitted to the Phonological and Reading Remediation Program); and GII, subdivided in: GIIE (10 students with learning disabilities submitted to the Phonological and Reading Remediation Program), GIIC (10 students with learning disabilities who were not submitted to the Phonological and Reading Remediation Program). As a procedure, in pre and post testing situations, the Cognitive-Linguistic Performance Test was applied. Results: the results showed statistically significant differences between GIE and GIC and between GIIE and GIIC, indicating that students who were submitted to the Program presented better performances in the post testing condition when compared to the pre-testing condition. Conclusion: this study showed that the Phonological and Reading Remediation Program was effective. The use of the Program improved perception, production and manipulation of sounds and syllables, interfering directly on the reading skills and comprehension of students with learning disabilities.
\end{abstract}

Key Words: Intervention; Learning Disabilities; Educational Status.

\section{Resumo}

Tema: Programa de Remediação Fonológica e Leitura no distúrbio de aprendizagem. Objetivo: verificar a eficácia terapêutica do Programa de Remediação Fonológica e Leitura em escolares com distúrbio de aprendizagem. Método: participaram deste estudo 40 escolares, sendo que estes foram divididos em: GI, subdivididos em GIE (10 escolares sem dificuldade de aprendizagem submetidos ao Programa de Remediação Fonológica e leitura), GIC (10 escolares sem dificuldade de aprendizagem não submetidos ao Programa de Remediação Fonológica e Leitura) e GII, subdividido em GIIE (10 escolares com distúrbio de aprendizagem submetidos ao Programa de Remediação Fonológica e Leitura), GIIC (10 escolares com distúrbio de aprendizagem não submetidos ao Programa de Remediação Fonológica e Leitura). Como procedimento foi aplicado o Teste de Desempenho Cognitivo-Linguístico, em situação de pré e pós-testagem antes da realização do Programa de Remediação Fonológica e Leitura. Resultados: os resultados evidenciaram diferença estatisticamente significante entre os GIE e GIC e GIIE e GIIC indicando que os escolares submetidos ao programa obtiveram melhor desempenho em situação de pós-testagem se comparado a pré-testagem. Conclusão: a realização deste estudo evidenciou que o Programa de Remediação Fonológica e Leitura foi eficaz, pois proporcionou melhora na percepção, produção e manipulação dos sons e sílabas, interferindo diretamente na habilidade de leitura e compreensão dos escolares com distúrbio de aprendizagem. Palavras-Chave: Intervenção; Transtornos de Aprendizagem; Escolaridade. 


\section{Introduction}

Learning disability is a differential diagnosis of developmental dyslexia and learning difficulty and it has been studied over the years under the perspective of diagnosis and intervention. The studies realized in last 20 years have demonstrated that the student with learning disabilities presents impairment in cognitive, linguistic, auditory and visual processing, and in this way, the triggering of cognitive mechanisms to analyze, synthesize, manipulate, store and evoke linguistic information is altered, damaging, thus, the learning of writing systems with alphabetical basis (1-3).

Therefore, in literature, the proposed intervention to students with learning disabilities is based on the teaching of metaphonological strategies aiming to develop attention and perception of speech sound in association with the mechanism of grapheme- phoneme conversion necessary for learning how to read and write (3-5).

The association of procedures that involve phonological awareness and reading has been focus of works realized with individuals with difficulties and learning disabilities. These studies have indicated the efficacy of such remediation programs associated to reading strategies (6-9). However, in spite of the recommendation on international literature to the use of such remediation program, in national literature the research about intervention programs with students who present learning disabilities is still scarce. Based on what was exposed above, this study aimed at verifying the therapeutic effectiveness of a phonological and reading remediation program in students with learning disabilities.

\section{Method}

This study was approved by the Committee of Ethics in Research of the Faculty of Philosophy and Sciences of the Universidade Estadual Paulista (CEP - FFC - Unesp) under the protocol number 2596/2007.

The participants of the study were 40 students from 2nd to 4th grades of municipal schools in Marília, from both genders, aged between 8 and 12 years old, divided into two groups:

Group I (GI): comprised 20 students without learning difficulties, 16 (80\%) males and 4 (20\%) females, subdivided into:

Group IE (GIE): comprised 10 students without learning difficulties submitted to phonological and reading remediation program.
Group IC (GIC): comprised 10 students without learning difficulties who were not submitted to phonological and reading remediation program.

The students without learning difficulties were indicated by the teachers based on satisfactory performance in two consecutive semesters in reading and writing exams. Before this indication, the students were submitted to ear-nose and throat, audiological and ophthalmological evaluation and the ones who participated in this study were those who showed results within normal standards.

Group II (GII): comprised 20 students with interdisciplinary diagnosis of learning disability, 19 (95\%) males and 1 (5\%) female, subdivided into:

Group IIE (GIIE): comprised 10 students with interdisciplinary diagnosis of learning disabilities who were submitted to phonological and reading remediation program.

Group IIC (GIIC): comprised 10 students with interdisciplinary diagnosis of learning disabilities who were not submitted to phonological and reading remediation program.

The diagnosis of learning disability of these students was made by an interdisciplinary team of the Center of Studies in Education and Health CSEH/UNESP - from Marília and the Ambulatory of Child Neurology - Learning Disorders of the Medical School - FM - UNESP - from Botucatu, including speech pathology, neurological, pedagogical, neuropsychological and neuroimage (Single Photon Emission Computed Tomography SPECT) evaluations.

The data collection was made at the Center of Studies in Education and Health - CSEH/UNESP after the signing of the Term of Free and Informed Consent by parents or caretakers of the students.

In situation of pre and post-testing every subject in this study was submitted to the same procedures to check the therapeutic efficacy of the program utilized. The selection of the procedure of pre and post-testing followed these criteria: instruments to verify single reading of words and non-words, phonological skill (rhyme and alliteration), reading and text comprehension (10). The following procedures were used in situation of pre and post testing:

A) Test of Cognitive-Linguistic Performance collective version: the collective version of the Test $(11,12)$ was used in all the students of the study simultaneously. This version is composed of the following subtests: alphabet recognition in sequence, forms copy, dictation and short-memory.

B) Test of Cognitive-Linguistic Performance individual version: the individual version of the Test 
$(11,12)$ was used in all the students of the study. This version is composed of the following subtests: reading, phonological awareness, auditory processing, writing, visual processing, speed and sequencing processing.

C) Oral Reading and Comprehension of Text: three texts were used, selected from the indication of 14 teachers of 2nd to 4th grades of municipal schools in Marília - SP. The teachers were asked to choose a text for each school grade among three options of texts. The texts with higher rate of approval from the teachers were selected for each grade for the realization of oral reading and text comprehension.

The comprehension of the text was conducted by the researcher, who soon after the reading of the text, asked the student to answer four questions. The analysis of the reading of the texts was realized by counting mistakes of the read words (reading accuracy), total time of reading and reading speed (13-14).

The phonological and reading remediation program was realized in 18 sessions with duration of 50 minutes each. The stages of the phonological remediation program were worked sequentially in the following order: identification of the sound and letters of the alphabet, identification of words inside a sentence, identification and manipulation of syllables in the word, phonemic synthesis, rhymes, identification and discrimination of phonemes, segmentation of phonemes, subtraction of phonemes, substitution and transposition of phonemes (APPENDIX 1).

The reading program was realized through the introduction of a book in the beginning of each session of phonological and reading remediation program. This program was developed with the use of books from the "Estrelinha" collection (1995) from Ática Publishers (15). The choice of this collection was made based on facilitating factors for reading acquisition (16), in other words, frequency of incidence of the word in writing; regularity in writing and lexicon (appropriate vocabulary for age and schooling). The level of difficulty of the book was modified when the student presented $94 \%$ of reading accuracy, in other words, a mistake or less in each 20 read words, in this way, the change in the degree of difficulty was realized after 2 sessions of reading books of the same degree. The collection of the sequential register of the reading was realized based on a protocol prepared for this finality that consists of registering information related to the number of words of each story, number of words read by minute, percentage of skill and mistakes typology.

The results were statistically analyzed by the program SPSS (Statistical Package for Social Sciences), version 13.0. The Mann-Whitney Test, Friedman Test and the Wilcoxon signed-rank test were also used. A level of significance of $5 \%(0,050)$ was adopted for the application of the statistical tests $(*)$.

\section{Results}

The results revealed improvement in the performance of the students who were submitted to the phonological and reading remediation program when the groups GIE, GIC, GIIE and GIIC were compared in pre and post-testing situation, as may be observed in Table 1, 2 and 3. 
TABLE 1. Distribution of the averages, standard deviation and significance (p) of the performance in pre and post-testing of the students from GIE, GIC, GIIE and GIIC in the skill of reading, writing and visual processing in the test of cognitive-linguistic performance - collective and individual version.

\begin{tabular}{|c|c|c|c|c|c|}
\hline Skill & Variable pair & Groups & Average & $\begin{array}{l}\text { Standard } \\
\text { deviation }\end{array}$ & Significance (p) \\
\hline \multirow{16}{*}{ Reading } & Alp_Pre & \multirow[t]{2}{*}{ GIE } & 26,00 & 0,00 & \multirow{2}{*}{$>0,999$} \\
\hline & Alp_Post & & 26,00 & 0,00 & \\
\hline & Alp_Pre & \multirow[t]{2}{*}{ GIC } & 26,00 & 0,00 & \multirow{2}{*}{0,317} \\
\hline & Alp_Post & & 25,90 & 0,32 & \\
\hline & Alp_Pre & \multirow[t]{2}{*}{ GIIE } & 24,00 & 2,21 & \multirow{2}{*}{$0,041^{*}$} \\
\hline & Alp_Post & & 25,80 & 0,42 & \\
\hline & Alp_Pre & \multirow[t]{2}{*}{ GIIC } & 23,10 & 2,60 & \multirow{2}{*}{0,796} \\
\hline & Alp_Post & & 22,60 & 4,65 & \\
\hline & R_Pre & \multirow[t]{2}{*}{ GIE } & 89,40 & 30,73 & \multirow{2}{*}{$0,005^{*}$} \\
\hline & R_Post & & 64,80 & 6,73 & \\
\hline & R_Pre & \multirow[t]{2}{*}{ GIC } & 88,50 & 28,45 & \multirow{2}{*}{$0,042 *$} \\
\hline & R_Post & & 77,40 & 23,00 & \\
\hline & R_Pre & \multirow[t]{2}{*}{ GIIE } & 231,80 & 93,03 & \multirow{2}{*}{$0,007 *$} \\
\hline & R_Post & & 164,20 & 91,21 & \\
\hline & R_Pre & \multirow[t]{2}{*}{ GIIC } & 246,80 & 101,27 & \multirow{2}{*}{0,507} \\
\hline & R_Post & & 217,30 & 116,36 & \\
\hline \multirow{16}{*}{ Writing } & WD_Pre & \multirow[t]{2}{*}{ GIE } & 24,40 & 1,17 & \multirow{2}{*}{$0,011^{*}$} \\
\hline & WD_Post & & 26,30 & 1,42 & \\
\hline & WD_Pre & \multirow[t]{2}{*}{ GIC } & 26,00 & 1,15 & \multirow{2}{*}{0,279} \\
\hline & WD_Post & & 26,40 & 0,97 & \\
\hline & WD_Pre & \multirow[t]{2}{*}{ GIIE } & 13,30 & 4,83 & \multirow{2}{*}{$0,005^{*}$} \\
\hline & WD_Post & & 18,50 & 5,04 & \\
\hline & WD_Pre & \multirow[t]{2}{*}{ GIIC } & 14,50 & 5,82 & \multirow{2}{*}{0,932} \\
\hline & WD_Post & & 14,50 & 6,70 & \\
\hline & NWD_Pre & GIE & 6,60 & 0,97 & 0250 \\
\hline & NWD_Post & & 7,20 & 0,92 & 0,250 \\
\hline & NWD_Pre & GIC & 7,40 & 1,17 & 0.429 \\
\hline & NWD_Post & & 7,70 & 0,95 & \\
\hline & NWD_Pre & GIIE & 3,20 & 1,32 & $0.011 *$ \\
\hline & NWD_Post & & 5,00 & 1,15 & \\
\hline & NWD_Pre & GIIC & 2,30 & 1,16 & 0.480 \\
\hline & NWD_Post & & 2,60 & 1,51 & \\
\hline & VM_Pre & GIE & 3,90 & 0,32 & 0317 \\
\hline & VM_Post & & 4,00 & 0,00 & \\
\hline & VM_Pre & GIC & 4,00 & 0,00 & $>0.999$ \\
\hline Visual & VM_Post & & 4,00 & 0,00 & \\
\hline Processing & VM_Pre & GIIE & 2,90 & 0,74 & $0009 *$ \\
\hline & VM_Post & & 4,00 & 0,00 & \\
\hline & VM_Pre & GIIC & 3,20 & 1,32 & 0.317 \\
\hline & VM_Post & & 3,10 & 1,37 & \\
\hline
\end{tabular}

Caption: Alp Pre: alphabet Pre-testing, Alp Post: alphabet Post-testing, R Pre: reading Pre-testing, R Post: reading Post-testing, WD Pre: word dictation, Pre-testing, WD Post: word dictation Post-testing, NWD Pre: non-words dictation Pre-testing, NWD Post: nonwords dictation Post-testing, VM Pre: visual memory with cartons Pre-testing, VM Post: visual memory with cartons Post-testing. 
TABLE 2. Distribution of the averages, standard deviation and significance (p) of the performance in pre and post-testing of the students from GIE, GIC, GIIE and GIIC in the skills of phonological awareness, auditory processing and speed processing of the test of cognitive-linguistic performance - collective and individual version.

\begin{tabular}{|c|c|c|c|c|c|}
\hline Skill & Variable pair & Groups & Average & $\begin{array}{r}\text { Standard } \\
\text { deviation }\end{array}$ & Significance (p) \\
\hline \multirow{16}{*}{$\begin{array}{c}\text { Phonological } \\
\text { Awareness }\end{array}$} & Alit_Pre & \multirow[t]{2}{*}{ GIE } & 9,70 & 0,67 & \multirow{2}{*}{0,180} \\
\hline & Alit_Post & & 10,00 & 0,00 & \\
\hline & Alit_Pre & \multirow[t]{2}{*}{ GIC } & 9,80 & 0,42 & \multirow{2}{*}{0,480} \\
\hline & Alit_Post & & 9,60 & 0,70 & \\
\hline & Alit_Pre & \multirow[t]{2}{*}{ GIIE } & 8,90 & 0,99 & \multirow{2}{*}{$0,026^{*}$} \\
\hline & Alit_Post & & 9,90 & 0,32 & \\
\hline & Alit_Pre & \multirow{2}{*}{ GIIC } & 7,00 & 2,62 & \multirow{2}{*}{0,071} \\
\hline & Alit_Post & & 7,80 & 2,20 & \\
\hline & Rhyme_Pre & \multirow[t]{2}{*}{ GIE } & 19,60 & 0,97 & \multirow{2}{*}{0,180} \\
\hline & Rhyme_Post & & 20,00 & 0,00 & \\
\hline & Rhyme_Pre & \multirow[t]{2}{*}{ GIC } & 19,70 & 0,95 & \multirow{2}{*}{0,414} \\
\hline & Rhyme_Post & & 19,40 & 1,07 & \\
\hline & Rhyme_Pre & \multirow[t]{2}{*}{ GIIE } & 14,30 & 5,93 & \multirow{2}{*}{$0,018^{*}$} \\
\hline & Rhyme_Post & & 17,80 & 2,44 & \\
\hline & Rhyme_Pre & \multirow[t]{2}{*}{ GIIC } & 11,60 & 6,15 & \multirow{2}{*}{0,797} \\
\hline & Rhyme_Post & & 11,80 & 5,18 & \\
\hline \multirow{16}{*}{$\begin{array}{c}\text { Auditory } \\
\text { Processing }\end{array}$} & SD_Pre & \multirow[t]{2}{*}{ GIE } & 19,60 & 0,97 & \multirow{2}{*}{0,180} \\
\hline & SD_Post & & 20,00 & 0,00 & \\
\hline & SD_Pre & \multirow[t]{2}{*}{ GIC } & 19,70 & 0,67 & \multirow{2}{*}{0,180} \\
\hline & SD_Post & & 20,00 & 0,00 & \\
\hline & SD_Pre & \multirow[t]{2}{*}{ GIIE } & 17,30 & 4,16 & \multirow{2}{*}{$0,043^{*}$} \\
\hline & SD_Post & & 19,60 & 0,97 & \\
\hline & SD_Pre & \multirow[t]{2}{*}{ GIIC } & 16,10 & 2,88 & \multirow{2}{*}{0,705} \\
\hline & SD_Post & & 16,20 & 3,16 & \\
\hline & WR_Pre & GIE & 5,00 & 1,15 & 0,157 \\
\hline & WR_Post & & 5,40 & 1,26 & \\
\hline & WR_Pre & GIC & 4,10 & 0,74 & 0,257 \\
\hline & WR_Post & & 4,40 & 0,70 & \\
\hline & WR_Pre & GIIE & 3,70 & 1,49 & 0.063 \\
\hline & WR_Post & & 4,30 & 0,95 & o \\
\hline & WR_Pre & GIIC & 2,90 & 0,99 & 0.414 \\
\hline & WR_Post & & 3,10 & 0,74 & \\
\hline & NN_T_Pre & GIE & 33,40 & 7,86 & 0,093 \\
\hline & NN_T_Post & & 32,40 & 7,73 & \\
\hline Speed & NN_T_Pre & GIC & 28,30 & 7,59 & 0,766 \\
\hline & NN_T_Post & & 28,70 & 5,85 & \\
\hline Processing & NN_T_Pre & GIIE & 39,70 & 7,75 & $0,016^{*}$ \\
\hline & NN_T_Post & & 33,70 & 6,20 & \\
\hline & NN_T_Pre & GIIC & 53,60 & 25,41 & 0,635 \\
\hline & NN_T_Post & & 54,30 & 20,56 & \\
\hline
\end{tabular}

Caption: Alit Pre: alliteration, Pre-testing, Alit Post: alliteration Post-testing, SD Pre: discrimination de sons Pre-testing, SD Post: sounds discrimination Post-testing, WR Pre: word repetition Pre-testing, WR Post: word repetition Post-testing, NN_T Pre: number naming time Pre-testing, NN T Post: number naming time Post-testing. 
TABLE 3. Distribution of the averages, standard deviation and significance (p) of the performance in pre and post-testing of the students from GIE, GIC, GIIE and GIIC in the reading and text comprehension test.

\begin{tabular}{|c|c|c|c|c|c|}
\hline Skill & Variables & Groups & Average & $\begin{array}{l}\text { Standard } \\
\text { deviation }\end{array}$ & Significance (p) \\
\hline \multirow{8}{*}{ Errors } & Errors_Pre & \multirow[t]{2}{*}{ GIE } & 7,80 & 4,71 & \multirow{2}{*}{$0,005^{*}$} \\
\hline & Errors_Post & & 3,00 & 2,91 & \\
\hline & Errors_Pre & \multirow[t]{2}{*}{ GIC } & 5,70 & 2,91 & \multirow{2}{*}{0,231} \\
\hline & Errors_Post & & 5,10 & 3,14 & \\
\hline & Errors_Pre & \multirow[t]{2}{*}{ GIIE } & 34,10 & 17,07 & \multirow{2}{*}{$0,009 *$} \\
\hline & Errors_Post & & 14,70 & 7,29 & \\
\hline & Errors_Pre & \multirow[t]{2}{*}{ GIIC } & 29,00 & 7,44 & \multirow{2}{*}{0,137} \\
\hline & Errors_Post & & 27,10 & 5,69 & \\
\hline \multirow{8}{*}{$\begin{array}{c}\text { Reading } \\
\text { Total } \\
\text { Time }\end{array}$} & TT_Pre & \multirow[t]{2}{*}{ GIE } & 169,80 & 58,12 & \multirow{2}{*}{0,284} \\
\hline & TT_Post & & 161,10 & 43,41 & \\
\hline & TT_Pre & \multirow[t]{2}{*}{ GIC } & 184,50 & 56,18 & \multirow{2}{*}{0,262} \\
\hline & TT_Post & & 165,60 & 43,72 & \\
\hline & TT_Pre & \multirow[t]{2}{*}{ GIIE } & 493,70 & 157,11 & \multirow{2}{*}{$0,007 *$} \\
\hline & TT_Post & & 369,70 & 127,46 & \\
\hline & TT_Pre & \multirow[t]{2}{*}{ GIIC } & 359,40 & 67,85 & \multirow{2}{*}{0,169} \\
\hline & TT_Post & & 382,40 & 90,44 & \\
\hline \multirow{8}{*}{$\begin{array}{c}\text { Reading } \\
\text { Speed }\end{array}$} & Speed_Pre & \multirow[t]{2}{*}{ GIE } & 97,87 & 32,45 & \multirow{2}{*}{0,153} \\
\hline & Speed_Post & & 100,91 & 32,31 & \\
\hline & Speed_Pre & \multirow[t]{2}{*}{ GIC } & 90,74 & 39,36 & \multirow{2}{*}{0,333} \\
\hline & Speed_Post & & 97,02 & 26,32 & \\
\hline & Speed_Pre & \multirow[t]{2}{*}{ GIIE } & 33,19 & 10,42 & \multirow{2}{*}{$0,011^{*}$} \\
\hline & Speed_Post & & 41,92 & 14,89 & \\
\hline & Speed_Pre & \multirow[t]{2}{*}{ GIIC } & 43,97 & 12,36 & \multirow{2}{*}{0,285} \\
\hline & Speed_Post & & 42,35 & 14,22 & \\
\hline \multirow{8}{*}{$\begin{array}{c}\text { Reading } \\
\text { Comprehension }\end{array}$} & Comp_Pre & \multirow[t]{2}{*}{ GIE } & 87,50 & 17,68 & \multirow{2}{*}{$0,046^{*}$} \\
\hline & Comp_Post & & 97,50 & 7,91 & \\
\hline & Comp_Pre & GIC & 67,50 & 26,48 & $0.041 *$ \\
\hline & Comp_Post & & 90,00 & 17,48 & \\
\hline & Comp_Pre & GIIE & 15,00 & 24,15 & $0.007 *$ \\
\hline & Comp_Post & & 67,50 & 16,87 & \\
\hline & Comp_Pre & GIIC & 20,00 & 15,81 & 0.157 \\
\hline & Comp_Post & & 30,00 & 22,97 & \\
\hline
\end{tabular}

Caption: Errors Pre: errors Pre-testing, Errors Post: errors Post-testing, TT Pre: time total Pre-testing, TT Post: time total Posttesting, Speed Pre: speed Pre-testing, Speed Post: speed Post-testing, Comp Pre: comprehension Pre-testing, Comp Post: comprehension Post-testing.

\section{Discussion}

The results of this study showed that, in the test of cognitive-linguistic performance, the students with learning disabilities, submitted to the phonological and reading remediation program, showed statistically significant results in all the skills if compared in situations of pre and posttesting. Our data are in agreement with studies that point to improvement in the performance of the students in the tasks of rhyme, alliteration, phonemic synthesis, phonemic segmentation and reading of words, after intervention, corroborating the influence of phonological awareness skills in reading and writing $(5,6,18)$.

In the phonological and reading remediation program, the improvement in the performance of the students in tasks of alphabet recognition, synthesis, segmentation, substitution and phonemic transposition suggests a relation between the 
learning of reading and phonological skills $(6,17,19)$. Our results agree with studies that point to a relation between the development of specific skills for reading and phonological awareness, once it was verified in the results that the increase of skills in letter identification was proportional to the improvement of performance in phonological tasks of identification and discrimination of phonemes and performance in reading. Thus, through the findings of our remediation study, it is possible to suggest that students who obtained benefits in knowledge of letters certainly showed greater competence in several skills, such as the phonological ones and reading $(6,8,18,20)$.

The students from GIE and GIIE showed better performance in tasks of syllabic identification and manipulation from the initial sessions of the remediation program indicating that the awareness of syllables is more perceptible than that of phonemes, according to what is described in literature $(6,17,19)$.

Our finds corroborate with studies described in literature $(5,10,19,20)$, because after the realization of a phonological remediation program associated with reading, the students with learning disabilities presented superior performance in tasks of phonological awareness, reading of non-words, automatic speed naming and phonological working memory. The performance of the students from this study in these tasks was modified after this type of combined intervention, because to each new book, a new visual vocabulary associated to the auditory vocabulary is introduced and that is why there is facilitation in the domain of the phonological awareness and of the retention in the short memory. According to mentioned literature, the visualization of the lexicon favors a better comprehension of the segmentation and manipulation of the phonological information, which for these students with learning disabilities is necessary, once they present difficulty in the use of generative mechanisms of phonological memory for perception and production of the spoken and read word.

Our results indicate that the groups that were submitted to the phonological and reading remediation program, GIE and GIIE, presented increase in the average of correct responses regarding their performance in the reading activities and text comprehension, if compared to GIC and GIIC, which suggests that directed activities of phonological awareness (phoneme/grapheme correspondence) associated to reading facilitate the initial learning of word reading, reading and text comprehension, in accordance to what is described in literature $(18,19)$.

Thus, according to the verification in the data of this study, among the students submitted to the phonological and reading remediation program it may be affirmed that there was a relation between the best performance on the knowledge of the letters, the phonological skill and the reading performance in words, non-words and text, once statistical signification occurred between the two moments of assessment. These findings must attract attention of speech and hearing therapists for the use of therapeutic programs that have an integrative approach like the ones presented in this article, in other words, ones that emphasize the use of hearing stimulus associated to visual stimulus to provide students with learning disabilities with better lexical formation and retention necessary for the learning of reading and text comprehension, according to proposed literature $(3,5,6)$.

\section{Conclusion}

The results of this study allow concluding that:

- The students from GIE and GIIE, submitted to phonological and reading remediation program, presented statistically significant difference when comparing their performances in pre and posttesting in the skills of reading, writing, phonological awareness, auditory processing, visual processing, speed processing, reading and text comprehension; - The achievement of this study evidenced that the phonological and reading remediation program was effective, since it provided increase in the perception, production and manipulation of sounds and syllables, what directly interfered in the skill of reading and text comprehension of the students with learning disabilities. 


\section{Appendix}

Examples of the activities proposed in phonological and reading remediation program.

1) Identification of sounds and of letters of the alphabet

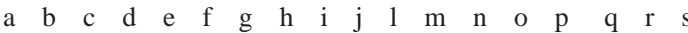

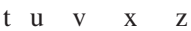

2) Identification of words inside a sentence

A menina está brincando na escola

Os meninos brincam de carrinho

O menino chutou a bola no vizinho

O pássaro voava com outros animais da floresta

Carol e Julia foram à feira comprar flores

Depois de comprar flores, Carol e Julia foram para casa

Os meninos estão correndo na rua

3) Identification and manipulation of syllables in the word

Machado - Macaco

Cavalo - Caderno

Futebol - Fumaça

Cobra - Colo

Rosa - Rocha

Pato - Palha

4) Phonemic synthesis

Nome

Rosa

Viola

Bonita

Famosa

Fita

Camelo

5) Rhyme

Mel - céu

Mato - Pato

Maço - Braço

Trave - Chave

Sozinha - Vizinha

Martelo - Castelo
6) Identification and discrimination of phonemes

- Target phoneme: /d/

Doce

Tatu

Antena

Bola

Droga

Danone

Bexiga

7) Phonemic segmentation

Peru

Peruca

Mato

Buraco

Vareta

Amarelo

Cabeça

8) Subtraction of phonemes

Initial

Final

Chuva - uva

Pés - pé

Ovo - vô

Curso -urso

Mar - má

Machado - achado

Pano - ano

Calor - calo

Osso - os

Sino - sim

Novo - ovo

Doces - doce

9) Substitution of phonemes

Bomba (/b/ por $/ \mathrm{t} /)$

Gente $(/ \mathrm{j} /$ por $/ \mathrm{k} /)$

Mola $(/ \mathrm{m} /$ por $/ \mathrm{s} /)$

Tapa $(/ \mathrm{t} / \mathrm{por} / \mathrm{k} /)$

Mala $(/ \mathrm{m} /$ por $/ \mathrm{s} /)$

Casa $(/ \mathrm{z} /$ por $/ \mathrm{r} /)$

10) Transposition of phonemes

Amú - uma

Missa - assim

Alé - ela

Ova - avó

Ola - alô

Las - sal

\section{References}

1. Heiman T, Kariv D. Manifestations of learning disabilities in university students. Implications for coping and adjustment. Education. 2004;(125):313-25.

2. Paula GR, Mota HB, Keske-Soares MA. A terapia em consciência fonológica no processo de alfabetização. PróFono Rev Atual Cient. 2005;(17):175-84

3. Silver CH, Ruff RM, Iveson GL, Barth JT, Broshek, DK, Bush SS, Koffer SP, Reynolds, CR. Learning disabilities: the need for neuropsycological evaluation. Arch Clin Neuropsychol. 2008;(23):217-19.
4. Guerra LB. A criança com dificuldade de aprendizagem: considerações sobre a teoria: modos de fazer. Rio de Janeiro: Enelivros; 2002.

5. Estell DB, Jones MH, Pearl R, Acker RV, Farmer TW, Rodkin PC. Peer groups, populatity, and social preference. trajectories of social functioning among students. With and without learning disabilities. J Learn Disabil. 2008;41 (1):5-14.

6. Wanzek J, Vaughn S. Response to varying amounts of time in reading intervention for students with low response to intervention. J Learn Disabil. 2008;41(2):126-42. 
7. Kamps D, Abbott M, Greenwood C, Wills H, Veerkamp M, Kaufman J. Effects of small-group reading instruction and curriculum differences for students most at risk in kindergarten. Two-year results for secondary - and tertiary - level interventioons. J Learn Disabil. 2008;41(2):101-14.

8. Calhoon MB. Effects of a peer-mediated phonological skill and reading comprehension program on reading skill acquisition for middle school students with reading disabilities J Learn Disabil. 2005;38(5):424-33.

9. Vaughn S, Linan-Thompson S, Mathes PG, Cirino PT, Carlson CD, Pollard-Durodola SD, Cardenas-Hagan E, Francis DJ. Effectiveness of Spanish intervention for firstgrade English language learners at risk for reading difficulties. J Learn Disabil. 2006;39(1):56-73.

10. Hatcher PJ, Hulme C, Ellis AW. Ameliorating early reading failure by integrating the reaching of reading and phonological skills: the phonological linkage hypothesis. Child Dev. 1994;(65):41-57.

11. Smythe I, Everatt J. Internacional Dyslexia Test (IDT). University of Surrey. 2000.

12. Silva C, Capellini SA, Gonzaga J, Galhardo MT, Cruvinel $\mathrm{P}$, Smythe I. Desempenho cognitivo - linguístico de escolares de $1^{\mathrm{a}}$ a $4^{\mathrm{a}}$ série do ensino publico municipal. Rev Assoc Bras Psic. 2007;24(73):30-44.

13. Capellini SA. Eficácia do programa de remediação fonológica em escolares com distúrbio específico de leitura e distúrbio de aprendizagem. [Tese]. Campinas: Universidade Estadual de Campinas; 2001.
14. Ramos CS. Avaliação de leitura em escolares com indicação de dificuldade de leitura e escrita. [Dissertação]. São Paulo: Universidade Federal de São Paulo; 2005.

15. Junqueira S. Coleção Estrelinha. São Paulo: Ática; 1995.

16. Clay MM. The early detection of reading difficulties. Oxford: Heinemann Educational, 1985.

17. Wanzek J, Vaughn S, Wexler J, Swanson EA, Edmonds M, Kim A. A synthesis of spelling and reading interventions and their effects on the spelling outcomes of students with LD. J Learn Disabil. 2006;39(6):528-43.

18. Savage RS, Frederickson N, Goodwin R, Patni U, Smith $\mathrm{N}$, Tuersley L. Relationship among rapid digit naming, phonological processing, motor automaticity, and speech perception in poor, average, and good readers and spellers. J Learn Disabil. 2005;38(1):12-28.

19. Ryders JF, Tunmer WE, Greaney KT. Explicit instruction in phonemic awareness and phonemically based decoding skill as an intervention strategy for struggling readers in whole language classrooms. Read Writ: Interd J 2008;(21):349-69.

20. Mann VA, Foy JG. Phonological awareness, speech development, and letter knowledge in preschool children. In: Speech development, perception, and production; components of reading. Ann Dyslexia. 2003;(53). 